\title{
Implementasi Nilai-Nilai Kepedulian Sosial Pada Peserta Didik Melalui Mata Pelajaran Al-Qur'an Hadits
}

\author{
Muhammad Habiburrohman \\ Pendidikan Agama Islam, Fakultas Pendidikan Agama Islam, Universitas Hasyim Asy'ari
}

\begin{tabular}{l}
\hline Article Info \\
\hline Article history: \\
Received 2019-10-12 \\
Accepted 2020-03-27 \\
\hline
\end{tabular}

\section{Keywords:}

Implementation of Values

Social Care

Qur'an Hadith

\begin{abstract}
Education is all the experiences that students go through with all lifelong environments, In a broad sense, education can be interpreted as a process with certain methods so that people gain knowledge, understanding, and ways of behaving in accordance with needs. While social science can be said to investigate the socio-cultural aspects of human education itself. Social can also be a reference in interacting between humans and society that functions to regulate the actions that are raised by individuals in the community. Based on the context of the above research the authors conducted research on "Implementation of Social Care Values in Students Through the Subjects of the Qur'an Hadith class XII (Case study at MAN 8 Jombang)" by using 3 research focuses as follows: (1) How is the role of the teacher of Al-Qur'an Hadith in fostering the values of social care for students in MAN 8 Jombang. (2) How to implement the values of social care for students in MAN 8 Jombang. (3) What are the supporting factors in fostering the values of social care for students in MAN 8 Jombang. The writer uses descriptive qualitative research with a qualitative approach. Data collection techniques using observation, interviews, and documentation. For data analysis techniques researchers use: data reduction, data display, data verification and conclusions. To check the validity of the data by means of: credibility testing, transfer testing, dependability testing and confirmability testing. The results show that: (1) teachers have an important role in fostering the values of social care in Madrasas. (2) The implementation of the values of social care through alqur'an hadith subjects went well and was successful, both within the Madrasah and the community. (3) the supporting and inhibiting factors, the supporting factors are the surrounding environment and peers, the inhibiting factor is controlling many students in Madrasas which require a long time
\end{abstract}

This is an open access article under the CC BY-SA license.

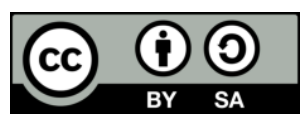

\section{Corresponding Author:}

Muhammad Habiburrohman

Pendidikan Agama Islam, Fakultas Pendidikan Agama Islam, Universitas Hasyim Asy’ari

Email: habibjr475@gmail.com

\section{PENDAHULUAN}

Pendidikan mempunyai pengertian segala pengalaman yang dilewati peserta didik dengan segala lingkungan sepanjang hidupnya, pendidikan juga bisa dipahami dengan memelihara dan memberi latihan. Dalam pengertian yang luas, pendidikan dapat dikatakan sebagai proses dengan cara-cara tertentu sehingga orang memperoleh pengetahuan, pemahaman, dan cara berperilaku yang sesuai dengan keperluan (Muhibin Syah, 2013: 10). Pada dasarnya kehidupan memiliki unsur pendidikan karena interaksi terhadap lingkungan, tetapi penting seharusnya para siswa-siswi menyesuaikan diri dan menempatkan diri sebaik mungkin dalam berinteraksi terhadap semua itu dan dengan siapapun. Manusia sebenarnya diciptakan oleh Tuhan sebagai seorang makhluk yang sadar. Kesadaran manusia itu sendiri disimpulkan dari kemampuannya berpikir, berkeinginan, dan merasakan. Dengan pikirannya manusia mendapatkan pengetahuan, dengan keinginannya manusia mengontrol perilakunya dan dengan perasaannya manusia dapat mendapat kesenangan. cara untuk 
memelihara dan meningkatkan pengetahuan disebut logika, sedangkan cara-cara untuk memelihara serta meningkatkan tingkah laku dan mutu kesenian, disebut etika dan estetika (Soenarjono Soekanto, 2001: 5).

Sosial ialah sesuatu yang digunakan sebagai tolak ukur dalam bercengkrama antara manusia dalam konteks masyarakat yang mana bersifat abstrak berkaitan dengan lingkungan yang berguna untuk mengatur perilaku yang dimunculkan oleh seseorang sebagai suatu masyarakat. Memperhatikan kepentingan umum dan berinteraksi juga dapat berarti sosial karena saling berhubungan menurut Bonner sosial ialah sesuatu hubungan antara dua manuisa atau lebih, di mana perilaku individu memengaruhi, merubah atau memengaruhi manusia lain atau sebaliknya.

Kesetaraan sosial diperlukan dalam hidup sehari-hari, karena apabila tidak berimbangnya sosial di lingkungan masyarakat itu sendiri maka akan memunculkan berbagai permasalahan yang menimbulkan perubahan terhadap kemasyarakatan itu sendiri. Adapun bentuk masalah sosial itu sangat bermacam-macam tergantung di mana kehidupan berada. Kepedulian sosial tidak mudah dimiliki begitu saja tanpa adanya dorongan baik itu berupa pendidikan atau pun pembiasaan (Abulsyani, 2012: 182).

Allah SWT berfirman dalam surat Al-Hujurat ayat 13 :

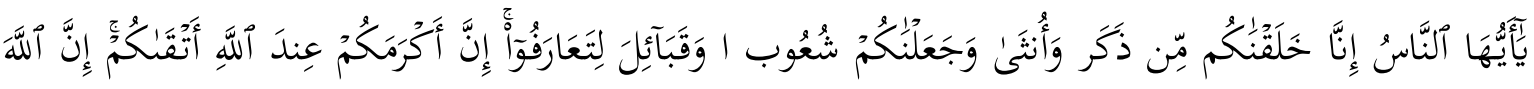

$$
\begin{aligned}
& \text { عَلِيمْ خَبِير }
\end{aligned}
$$

Artinya : Hai manusia! sungguh Kami telah menjadikan kamu dari laki-laki dan perempuan lantas kami menciptakan kamu berbangsa-bangsa dan bersuku-suku supaya kamu saling mengetahui. Sungguh, yang paling mulia di antara kamu di sisi Allah yakni orang-orang yang paling bertaqwa. Sungguh, Allah Maha Mengetahui, Maha teliti”. (QS. Al-Hujurat (49): 13)

Ayat di atas memberikan arti bahwa Allah SWT menjadikan manusia dengan bermacam-macam bangsa dan suku agar saling mengetahui dan saling membantu dalam kehidupan, karena sejatinya manusia adalah makhluk sosial manusia tidak dapat hidup tanpa berdampingan dengan yang lain. Karena itulah Allah menciptakan manusia dengan berbagai macam bangsa, suku, ras, hanya agar supaya mereka saling mengenal sehingga dapat hidup berdampingan.

\section{METODE}

Penelitian ini memakai pendekatan kualitatif dengan jenis penelitian studi kasus. Pendekatan kwalitatif dengan bentuk penelitian studi kasus ini diambil sebab pada penelitian ini berusaha memahami fenomenafenomena social, di karenakan berhubungan langsung terhadap gejala-gejala yang hadir atau ada di lingkungan individu yang terorganisiir di dalam suatu pendidikan, dari di lingkungan Madrasah hingga di lingkungan bermasyarakat.

Data primere yakni data yang didapat dari rujukan pertama ketika melakukan penelitian, dengan melalui prosedur serta tehnik pengumpulan data yang bisa berbentuk interviiew, obsevasi, atau pun penggunaan instrumen yang khusus dibentuk sesuai pada harapan. Adapun data primeer yang penulis pakai berupa beberapa informen, data secara langsung dari MAN 8 Jombang, dalam berupa data peserta didik, guru, atau pun arsip lain yang dapat didapatkan dari tempat penelitian. kemudian data sekunderr yaitu data yang didapat berasal sumber tidak langsung yang mana biasanya berbentuk data dokumeentasi dan arsiip-arsip resmi. Latar penelitian yang dilakukan oleh peneliti yakni di MAN 8 Jombang. Alasan peneliti memilih lokasi ini karena realitasnya di MAN 8 Jombang tersebut menerapkan kepedulian sosial. Rentang waktu yang dibutuhkan peneliti dalam penelitian ini perkiraan dari bulan januari 2019 sampai bulan maret 2019. Bagaimana peran guru mata pelajaran Al-Qur'an Hadits dalam menumbuhkan nilai-nilai kepedulian sosial pada peserta didik di MAN 8 Jombang? Bagaimana implementasi nilai-nilai kepedulian sosial pada peserta didik di MAN 8 Jombang? Apakah faktor-faktor pendukung dalam menumbuhkan nilai-nilai kepedulian sosial pada peserta didik di MAN 8 Jombang? Untuk megetahui peran Guru mata pelajaran AL-Qur'an Hadits dalam menumbuhkan nilai-nilai kepedulian sosial pada peserta didik di MAN 8 Jombang. Untuk mengetahui bagaimana implementasi nilainilai kepedulian sosial pada peserta didik di MAN 8 Jombang. Untuk megetahui faktor-faktor penduukung dalam menumbuhkan nilai-niilai kepedulian sosial pada peserta didik di MAN 8 Jombang.

\section{HASIL DAN PEMBAHASAN}

Peduli ialah nilai dasar dan perilaku memerhatikan dan bertingkah laku aktif pada kondisi atau keadaan sekitar tempat tinggal. Orang yang perduli bisa disebut juga orang-orang ingin melakukan sesuatu dalam rangka memberi dorongan, perubaham, kebaikan untuk saling membantu sesama, dan hatinya akan tergerak untuk membantu orang lain untuk mengharapkan akan dapat memperbaiki ataua membantu kondisi sekitar. Manusia hidup di dunia ini pasti memerlukan orang lain untuk kehidupannya, sebab pada sejatinya manusia 
adalah makhluk sosial. Dikatakan oleh Buchari Alma makhluk sosial memiliki arti yakni hidup menyendiri akan tetapi sebagian besar kehidupanya saling kebergantungan, yang mana pada akhir tujuannya akan mendapat keseiimbangan relatif. Dari semua itu, pada dasarnya manusia mempunyai kepedulian sosial kepada sesama makhluk hidup alinnya, sehingga terjadilah keberimbangan di alam hidup.

Sosial adalah ilmu yang menyelidiki aspek sosio kultural pendidikan manusia. Sosial juga bisa sebagai acuan dalam berinteraksi antara manusia dengan masyarakat yang berguna untuk mengakomodir tingkah laku yang ditunjukkan dari individu untuk masyarakat (Abu Achmadi, 2017: 2). Memperhatikan kepentingan umum berinteraksi juga dapat disebut sebagai sosial karena saling berhubungan. Berbincang tentang interaksi sosial sebenarnya sama saja membicarakan sesuatu yang sangat fundamental dalam kehidupan manusia. Manusia juga seharusnya bisa berinteraksi dengan manusia lainnya dan dengan lingkungannya. Senada dengan walgito, bonner, sebagaimana dikutip Gerungan memberi pengertian bahwa hubungan sosial ialah sesuatu relasi di antara satu, dua tau lebih individu, di mana manusia yang satu dan manusia yang lain saling mempengaruhi, mengubah atau memperbaiki (Siti Mahmudah, 2010: 67). Kepedulian sosial terdapat dua kata yakni, "peduli" dan "sosial" peduli mempunyai arti mengiindahkan atau memerhatikan, sebagaimana sosial memiliki arti suka atau memerhatikan urusan umum. Dengan begitu kepedulian sosial ialah perilaku saling peduli dan memerhatikan satu sama lain untuk memperhatikan kondisi sosial masyarakat.

Manusia sebagai makhluk sosial tentu tidak akan bisa memisahkan kehidupanya dengan individu lain. Sudah tidak jadi rahasia lagi karena segala macam kebudayan, tatanam kehidupan, dan sistim masyarakat terjadi sebab hubungan dan tuntutan kepentingan dari satu individu dengan individu lainnya. Keutuhan individu akan terjadi bilamana individu mampu menyelaraskan tugasnya menjadi makhluk ekonomi dan sosial. menjadi makhluk sosial (homo socialis), seseorang bukan saja menggunakan kemampuannya sendiri, sebab memerlukan orang lain pada sebagian hal tertentu, dan pada seharusnya saling memuliakan, menyayangi, dan juga perduli kepada macam-macam keadaan di lingkungan sekitarnya. Adapun nilai-nilai sosial terdiri dari 3 sub: Love (kasih sayang) yang tersusun atas pengabdian, tolong-menolong, gotong royong, kekeluargan. Responsibility (tanggung jawab) rasa empati dan saling memiliki. Life harmoony (kesesuaian hidup) yakni terdiri atas keberadilan, kerjasamaa dan toleransi.

Pada ulasan di atas diketahi ykni nilai-nilai sosial bisa dijadikan pedoman bagi siswa dan bisa diterapkan siswa di dalam maupun luar sekolah. Dan siswa tidak akan mempunyai rasa egois, dan tidak peduli terhadap lingkungan sekitar. Selain penanaman nilai-nilai sosial pada anak, guru juga harus mencontohkan prilaku yang baik atau prilaku positif untuk peserta didik agar peserta didik dapat mempraktekkan kepada masyaarakat atau lingkungan sekitar. Pembahasan umum tentang pelajaran Al-Quran Hadit. Pemahaman pembelajaran Al-Quran Hadis. Pemahaman adalah proses belajar dan berpikir. Karena untuk mengarah kepemahaman yaitu dengan belajar dan berpikir. Pemahaman bisa dikatakan proses tingkah laku dengan cara mengerti apa yang sudah kita pelajari.

Pembelajaran Al-Quran dan Hadis sebagai tonggak yang penting dari pendidikan Agama, walaupun tidak satu-satunya penyebab yang menjadi penentu dalam membentuk watak dan kepribadian pelajar, meski begitu secara substansial mata pelajaran AlQuran dan Hadis mempunyai peran dalam menyalurkan motivasi kepada peserta didik untuk mempraktikkan nilai-nilai kegamaan (tauhid/tuhan) dan Akhlakul kariimah di kehidupannya sehari-hari. Mata pelajaran AlQur'an Haditss ialah salah suatu bentuk dari pembelajaran Pendidikan Agama Islam di Madrasaah Aliyah dengan dimaksudkan yakni memberi motivasi, bimbingan, pengertian, kepintaran dan penghayataan pada isi yang terdapat dalam Al-Quraan dan Hadits akhirnya dapat diimplementasikan kepada tata krama sehari-hari sebagai perwujudan iman dan takwa pada Allah SWT.

Islam merupakan agama tauhid memerhatikan masalah yang mana berterkaitan terhadap kemanusiaan, salah satunya judul penting dalam AL-Qur'aan dan Hadiits yaitu kemiskinan dan cara mengatasinya (Rifqi Rusyidi, 2016: 5). Dalam mata pelajaran Al-Qurr'an Hadits ada beberapa point penting mengenai kepedulian sosial salah satunya yakni tentang hidup sederhana dan menyantuni dlu'afa'. Peserta didik tentu diharapkan mampu mengimplementasikan pelajaran tersebut didalam kehidupan nyata agar jiwa peduli sosial tumbuh pada diri mereka. Pertama, Pengertian AL-Qur'an. Al-Quran dilihat dari segi etimologi terdiri dari kata " "قر " yang memiliki arti sesuatuu yang dibaca. Intinya Al-qur'an secara bahasa ialah suatu yang dibaca (Abdul Majid Khon, 2011: 1). Dikatakan oleh imam Ass-Suyuti dalam bukunya Zein Amirudin memberi pemahaman bahwa al-qur'an ialah kalaamullah (fiirman Allah) yang di wahyukan pada Nabi Muhammad SAW untuk melemahkan orang-orang yang melawannya, meskipun sekadar satu surah padanya (Zein Amirudin, 2009: 47)

Dilihat dari sudut terminologi Al-Quraan ialah kalam Allah Swt. Al-Qur'an diturunkan kepada Rasulullah Muhammad SAW. melalui wahyu yang dibawa oleh jibril, baik lafazh maupun maknanya. Membacanya merupakan ibadah, sekaligus merupakan mukjizat yang sampai kepada kita secara mutawatir. Kedua, Definisi Hadis. Hadis yakni salah satu pedoman yang dipakai oleh orang Islam dalam melakukan macam-macam kegiatan baik yang berhubungan dengan urusan-urusan dunia ataupun kegiatan yang berhubungan dengan urusan akhirat. Hadiits menjadi rujukan hukum agama Islam yang kedua setelah kitab suci Al Qur'an. kalau sesuatu masalah tidak dijelaskan pada Al -Qur'an, maka orang Islam akan memakai rujukan yang kedua yakni

Muhammad Habiburrohman (Implementasi Nilai-Nilai Kepedulian Sosial Pada Peserta Didik ...) 
Hadits.

Istilah hadiits sejatinya diambil dari bahasa Arab yakni dari kata "Al-hadits" yaitu artiinya ialah perkatan, percakaapan atau pun berbiicara. bila diartikan dari kata asalnya, jadi definisi hadis adalah tiap tulisan yang berawal dari ucapan atau pun obrolan Rasulullah Muhammad SAW. Menurut terminologi agama Islam itu sendiri, di paparkan bahwa hadiits ialah tiap tulisan yang melaporan atau pun menyatat semua ucapan, perbuatan dan perilaku Nabi Muhammad SAW.

Peneliti menggunakan pendekatan kualitatif dengan jenis penelitian study kasus. Pendekatan kualiitatif dengan jenis penelitiian study kasus ini diambil sebab pada penelitian ini berusaha memahami fenomeenafenomena social, dikarenakan berhubungan langsung terhadap sebab-sebab yang timbul atau ada di lingkungaan manusia yang teroganisir pada suatu pendidikan, di lingkungan madrasah hingga di lingkungan bermasyarakat. Penyajian data tentang bagaimana implementasi nili-nilai kepedulian sosial pada peserta didik melalui AL-Qur'an Hadiits di MAN 8 Jombang, pembelaajaran Al-qur'an Hadis yang ada di MAN 8 Jombang terdapat beberapa materi pembahasan yang berhubungan langsung dengan kepedulian sosial, yang mana dalam proses pembelajarannya mengajak secara langsung peserta didik untuk mempraktikkan materi yang berkaitan dengan kepedulian sosial tersebut.

Bedasarkan penelitian yang telah peneliti lakukan di MAN 8 Jombang, implementasi nilai-nilai kepedulian sosial pada peserta didik melalui mata pelajaran al-qur'an hadits kelas XII di MAN 8 Jombang sudah menjadi karakter tersendiri bagi siswa maupun siswi, karena di dalam mata pelajaran al-qur'an hadits itu sendiri sudah ada bab-bab yang berhubungan tentang kepedulian sosial, seperti bab tentang menyantuni kaum dhu'afa', amar ma'ruf nahi munkar.

Ada beberapa program yang ada di lingkungan Madrasah yang berkaitan dengan kepedulian sosial, seperti program kamis amal yang mana pada setiap hari kamis osis akan keliling ke setiap kelas untuk meminta sumbangan, sasaran kamis amal ini tidak hanya para peserta didik melainkan para guru dan seluruh civitas akademika di Madrasah, hasil program kamis amal akan digunakan ketika ada musibah yang dialami peserta didik maupun keluarganya baik itu kecelakaan, meninggal dunia, dan lain-lain. Selain itu juga akan digunaka untuk membantu korban bencana yang ada di tanah air dengan bekerjasama dengan kemenag. Program lainnya yang diadakan setiap tahunnya adalah berbagi daging qurban, yang mana pengolahan hewan qurban itu dilakukan oleh para peserta didik dan juga para guru. Dengan melibatkan peserta didik, para peserta didik akan tumbuh jiwa kepedulian sosialnya di lingkungan Madrasah maupun di lingkungan masyarakat.

Faktor pendukung maupun penghambat selalu ada dalam program madrasah maupun lembaga dalam mencapai tujuan yang diharapkan, lembaga harus mengetahui apa saja yang menjadi faktor penghambat maupun pendukung agar dapat dievaluasi sehingga program yang ada di Madrasah dan lembaga berkembang, apalagi dalam implementasi nilai-nilai kepedulian sosialmpada peserta didik melalui mata pelajaran al-qur'an hadits kelas XII di MAN 8 Jombang ini terdapat faktor yang harus dievaluasi, agar ke depannya proses pembelajaran dan pemahaman peserta didik lebih baik lagi.

Untuk faktor penghambat selama ini yang dialami oleh peserta didik sendiri adalah faktor pergaulan, dalam lingkungan Madrasah terdapat banyak sekali individu dengan berbagai macam suku, budaya, ras, dan lain-lain. Dari sekian banyak perbedaan itu dipertemukan dalam suatu lingkup pembelajaran yakni di dalam kelas, dengan banyaknya macam-macam individu tersebut tentu akan mempunyai tingkah laku dan sikap yang berbeda-beda baik di lingkungan Madrasah maupun lingkungan masyarakat dan juga teman sejawatnya. Karena sering bertemunya dengan teman dari berbagai macam suku tersebut tentu saja akan membawa efek baik maupun buruk kepada individu, tidak semua individu dari berbagai macam suku tersebut memiliki sikap yang baik tidak sedikit dari mereka yang memiliki sikap kurang baik sehingga ini lah yang diatakutkan akan mempengaruhi individu yang lain ketika berteman dengan individu tersebut. Kemudian ada faktor sikap egois, peserta didik memiliki banyak sekali sikap dan tingkah laku kesehariannya di lingkungan Madrasah maupun di lingkungan masyarakat. Ada yang memiliki sikap empati yang tinggi tak sedikit juga yang memiliki sikap acuh tak acuh terhadap lingkungan sekitarnya, kita tidak bisa memukul rata bahwa semua peserta didik memiliki sikap peduli sosial yang tinggi. Sikap egois yang dimiliki peserta didik akan memberikan efek buruk terhadap perkembangannya dalam berbagai hal, salah satunya yakni efek buruk terhadap sikap kepedulian sosialnya di lingkungan Madrasah maupun lingkungan masyarakat.

Faktor pendukung implementasi nilai-nilai kepedulian sosial melalui mata pelajaran al-qur'an hadits kelas XII di MAN 8 Jombang di antaranya adalah guru, Tidak bisa dipungkiri guru merupakan salah satu elemen penting bagi berjalannya pendidikan di lingkungan Madrasah, guru sebagai fasilitator dalam proses pembelajaran yang juga mempunyai tugas menyampaikan penegetahuan kepada pesertra didik dan tentunya dalam pengaplikasiannya dari materi yang sudah di ajarkan tentu guru memiliki peran yang sangat penting yakni dengan memberikan gambaran atau contoh yang baik kepada siswa yang berhubungan dengan materi yang di sampaikan, dengan begitu peserta didik akan lebih termotivasi dalam mengaplikasikan materi tersebut pada kehidupannya sehari-hari sebagaimana di lingkungan Madrasah maupun lingkungan bermasyarakat. Karena dengan guru memberikan contoh dan tauladan bagaimana cara pengaplikasiannya materi yang sudah 
di ajarkan dalam kehidupan sehari-hari, peserta didik akan lebih paham dan mengerti serta dapat mempraktikkannya dalam kehidupan mereka. Kemudian ada faktor lingkungan, lingkungan merupakan tempat bertemunya banyak individu yang mana dalam kesehariannya mereka akan sering bertemu, berinteraksi dalam berbagai hal sehingga menimbulkan interaksi sosial. Hal ini yang menyebabkan adanya perubahan sikap sosial pada satu individu, lingkungan berperan sangat penting dalam menumbuhkan sikap sosial salah satunya pada peserta didik. Dalam masyarakat kita akan banyak sekali menemukan kegiatan-kegiatan yang berhubungan dengan sosial seperti gotong royong salah satunya, yang mana sering kali kita jumpai dalam lingkungan masyarakat. Dengan adanya kegiatan seperti itu individu-individu secara tidak langsung akan terpengaruh dan tergerak hatinya, sehingga tumbuhlah sikap peduli sosial yang tinggi antar sesama individu. Hal demikian lah yang bisa menjadi salah satu faktor pendukung dalam menumbuhkan nilai-nilai kepedulian sosial kepada peserta didik baik di lingkungan Madrasah maupun lingkungan masyarakat

\section{KESIMPULAN}

Maka secara garis besar dapat disimpulkan, implementasi nilai-nilai kepedulian sosial pada peserta didik melalui mata pelajaran Al-Qur'an hadits kelas XII di MAN 8 Jombang. Pembelajaran Al-qur'an Hadis yang ada di MAN 8 Jombang terdapat beberapa materi pembahasan yang berhubungan langsung dengan kepedulian sosial, yang mana dalam proses pembelajarannya mengajak secara langsung peserta didik untuk mempraktikkan materi yang berkaitan dengan kepedulian sosial tersebut.

Dalam Implementasi nilai-nilai kepedulian sosial melalui mata pelajaran al-qur'aan hadis kelas XII di MAN 8 Jombang, ada yang di implementasikan secara individu dan ada yang di implementasikan secara berkelompok dan secara kelembagaan, berawal dari pemahaman yang kemudian mengimplentasikan atau mengaplikasikan kepedulian sosial tersebut melalui mata pelajaran Al-Qur'an hadits dalam banyak aspek di MAN 8 Jombang, yang mana di dalam mata pelajaran AL-Qur'an Hadits tersebut terdapat beberapa materi yang kaitannya erat sekali dengan kepedulian sosial, materi ini di ajarkan kepada peserta didik dengan harapan setelah mempelajari materi tersebut, peserta didik sadar bahwa sejatinya manusia di ciptakan berbangsabangsa, berbagai macam suku, agar mereka saling mengenal kemudian melengkapi satu sama lain dan mereka juga sadar bahwa manusia sejatinya adalah makhluk sosial yang mana hidup berdampingan dengan yang lainnya, seseorang tidak mampu hidup sendirian. Para peserta didik sadar mereka akan membutuhkan bantuan dan pertolongan orang lain dalam hal apapun, dengan adanya pemahaman seperti itu peserta didik akan sadar bagaimana pentingnya memiliki sifat peduli sosial terhadap sesama manusia. Secara individu peserta didik akan merasakan apakah mereka sudah memiliki sifat peduli sosial atau belum, dengan begitu mereka akan introspeksi diri setelah menerima dan memahami materi-materi yang sudah dia ajarkan oleh guru mereka. Adapun yang peserta didik lakukan setelah mendapatkan materi pembelajaran tentang kepedulian sosial yakni bagaimana mereka akan menerapkannya pada kehidupan sehari-harinya, secara tidak langsung mereka akan tergerak hatinya ketika melihat kejadian-kejadian di sekitar mereka yang mana kejadian tersebut erat sekali kaitannya dengan kepedulian sosial.

\section{REFERENSI}

Abulsyani, Sosiology Skematiika Teori dan Terapan, Jakarta: PT Bumi Aksara, 2012.

Achmadi, Abu, Sosiologi Pendiidikan, Jakarta: PT Rieneka cipta, 2017.

Amiruddin, Zen, Ushul Fiqih, Yogyakarta: Teras, 2009.

Alma, Buchari dan Harlas gunawan, Hakikat Dasar Study Sosial, Bandung: Sinar Baru, 1987

Ahmadi, Rulam, Metode Penelitian kualitatif, Yogyakarta: Ar-Ruzz Media, 2016.

Barrizi, Achmad dan Idriis, Muhammad, Menjadi Guru Unggul, Yogyakarta: Ar-Ruzz Media, 2010

Daradjat, Zakiah dkk, Ilmu Pendidiikan Islam, Jakarta: Bumi Aksara, 2018.

Depag Republik Indonesia AL-Qur'an dan Terjemahannya: Juz 1 - Juz 30, Bekasi: Cipta

Bagus Segara, 2011.

Gerungan, Psikologi Sosial, Bandung: PT Refika Adiatama, 2010.

Iskandar, Metodologii Penelitian Pendidikan dan Sosial Kwantitatif Kwalitatif, Jakarta: Garung Persada, 2008. Khon, Abdul Mazid, Praktikum Qiraat, Jakarta: Hamzah, 2011.

Mahmudah, Siti, psikologi sosial, Malang, UIN-Malik Perss, 2010.

Moloeng, Lexy J., Metode Penelitian Kwalitatif, Kwantitatif, Bandung: Remaja Rosidakarya, 2016. 
Nasution, S, Sosiologi Pendidikan, Jakarta: Bumi Aksara, 2014.

Pujileksono, Sugeng, Metode Penelitian Kualitatif, Malang: Kelompok Instans Publishing, 2015.

Soehartono, Irawan, Metode Penelitian Social, Bandung: PT. Remaja Rosidakarya,

2015.

Syah, Muhibin, Psikology Pendidikan, Bandung: PT. Remaja Rosidakarya, 2013.

Sukmadiinata, Nana Saodih, Landasan Psikologi Proses Pendidikan, Bandung: PT Remaja Rosdakarya, 2005.

Sujono, Belajar dan Pembelaajaran Teori dan Konsep Dasar, Bandung: PT. Remaja Rosidakarya, 2015.

Soekanto, Soenarjono, Sosisologi Suatu Pengantar, Jakarta: PT. Radja Grafiindo Persada, 2001.

Sukardi, Metode Penelitian Pendiidikan, Jakarta: PT Bumi Aksara, 2014.

Suwartono, Metodologi Penelitian, Yogyakarta: CV Andi Offset, 2014.

Sugiono, Metode Penelitian Pendidikan Pendekatan Kwantitatif, Kwalitatif, dan R\&D, Bandung: Alfaebeta, 2016. 